\title{
前立腺癌の放射線療法
}

\author{
千葉大学医学部泌尿器科学教室（主任：島崎 淳教授） \\ 秋元 晋 布施 秀樹 島崎 淳 \\ 放射線医学総合研究所 (所長 : 寺島東洋三) \\ 森田新六恒元博
}

\section{RADIOTHERAPY OF PROSTATIC CARCINOMA}

\author{
Susumu Akimoto, Hideki Fuse and Jun Shimazaki \\ Department of Urology, School of Medicine, Chiba University \\ (Director: Prof J. Shimazaki) \\ Shinroku Morita and Hiroshi Tsunemoto \\ National Institute of Radiological Sciences \\ (Chief: T. Terashima)
}

During the period from 1976 to 1985,28 cases with adenocarcinoma of the prostate localized in the pelvis (Stage $A_{2} ; 3$, Stage $B_{1} ; 4$, Stage $B_{2} ; 1$, Stage $C, N x ; 13, C, \mathrm{pN}_{0} ; 5, C, \mathrm{pN}_{1}\left(D_{1}\right) 2$ ) underwent curative external radiotherapy. 21patients were treated by $100 \sim 131 \mathrm{TDF}$ of fast neutron combined with or without Lineac X-ray and 7 cases were treated by 6,000 7,000 rad of Lineac X-ray. The radiation fields were prostate in 13 , small pelvis and prostate in 13 , and small pelvis in 2.

16 patients were well controlled by radiation therapy, but 12 patients relapsed and were followed by endocrine therapy. The types of relapse were local growth in 3 , distant metastases in 7 , both in 1 and unknown in 1 . These relapses occurred in the cases of large prostate cancer, small radiation field in $\mathrm{Nx}$ patients or low radiation dose.

The three-year disease-free survival rates of Stage $\mathrm{A}_{2}, \mathrm{~B}, \mathrm{C}$ were $100 \%, 53 \%, 52 \%$, respectively, and the five-year overall survival rates were $100 \%, 100 \%, 59 \%$, respectively. Since $64 \%$ of the patients who were added with endocrine therapy were controlled for more than 2 years, endocrine therapy seems to be effective in the case of failure after radiotherapy. Severe complication which needed surgical treatment was in 1 case of sacral decubitus.

It was concluded that external radiotherapy was a good modality for prostate cancer localized in the pelvis.

要旨：千葉大学医学部泌尿器科において，1976年から1985年までの間に，放射線療法にて治療を開始し た末治療前立腺癌のうち，骨盤内に限局する病期（Stage $\mathrm{A}_{2} 3$, Stage B 5, Stage C,Nx 13, Staging Operation 施行 $\left.\mathrm{C}, \mathrm{pN}_{0} 5, \mathrm{D}_{1}, \mathrm{pN}_{1}, 2\right)$ のものの予後を検討した. 速中性子線単独あるいはリニアック $\mathrm{X}$

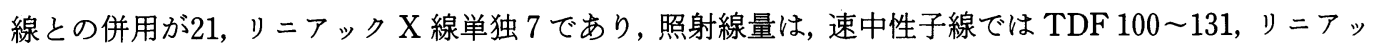
ク X 線では6,000〜7,000 rad をおこなった．照射野は原発巣のみ 13 ，小骨盤と原発巣 13 ，小骨盤のみ 2 である，放射線療法で制癌中のものは16で，再発し内分泌療法を追加したものは12であった，後者の再 発様式は，局所の制御不充分 3 , 遠隔転移十局所の制御不充分 1 , 遠隔転移のみ 7 , 転医により不明 1 である。制癌し得なかった原因は，大きな原発巣，照射野設定不良，低線量に帰せられた。 3 年非再発 率は, Stage $\mathrm{A}_{2} 100 \%$, Stage B 53\%, Stage C 52\%であり，5年生存率は Stage $\mathrm{A}_{2} 100 \%$, Stage B 100\%, Stage C 59\%であった. 内分泌療法追加により 64\%が有効であることより, 放射線療法後に再発 した場合にも内分泌療法が有効であった。放射線障害で，外科的処置が必要であったのは，仙骨部裖瘡 の 1 例のみであった。

以上より，骨盤内に限局せる前立腺癌に対する放射線療法の有効性を確認した。 


\section{緒 言}

欧米に扣いては，Stage C 以下の前立腺癌に対する 根治的治療法としての放射線療法は, 有用性が認めら れ，約 20 年前より広く行なわれているが'1)，本邦に拉い ては，普及が遅れて実施されつつある2).千葉大学にお いては，未治療前立腺癌に対し，速中性子線を用いた 放射線療法が優れた制癌効果をみることを，すでに発 表した ${ }^{3)}$. 今回, 放射線療法の第 1 適応である骨盤内限 局癌に対する効果を, その後の症例を加えて検討した。

\section{症例および治療方法}

対象症例：1976年から1985年をでに千葉大学医学部 泌尿器科を受診した骨盤内に限局した未治療の前立腺 癌28例（内訳は, Stage $\mathrm{A}_{2} 3$, Staging Operation 未 施行の Stage $B_{1} 4$, Stage $B_{2} 1$, Stage $C(\mathrm{C}, \mathrm{Nx})$ 13. Staging Operationを施行し, $\mathrm{pN}_{0}$ のもの5 ( C, $\left.\mathrm{pN}_{0}\right), \mathrm{pN}_{1}$ のもの2 (C, $\left.\mathrm{pN}_{1}\left(\mathrm{D}_{1}\right)\right)$ の症例を対象とし た. 本論文では, $\mathrm{C}, \mathrm{Nx}, \mathrm{C}, \mathrm{pN}_{0}$ および $\mathrm{C}, \mathrm{pN}_{1}\left(\mathrm{D}_{1}\right)$ の 3 つを一括して Stage $C$ とした. 年齢は 48 歳から85歳 までで，40歳台 1 例，50歳台 1 例，60歳台 11 例， 70 歳 台 13 例, 80 歳台 2 例, 平均 70.0 歳であった。病理組織 分化度は Gleason score 分類 ${ }^{4}$, 及び前立腺癌取扱い規 約の組織学的分類法 ${ }^{5}$ によった。 な拉, Stage C の予後 を比較するために, 歴史的対照として, 1961年から1985 年までの期間に初回治療として内分泌療法を行った 46 例を用いた。

治療方法: 速中性子線は, 放射線医学総合研究所の $30 \mathrm{MeV}(\mathrm{d} \rightarrow \mathrm{Be})$ サイクロトロン装置を用い，一部の 症例はリニアック $\mathrm{X}$ 線との混合照射を併用した。 照射 野が小骨盤の場合は, 腸管の障害を少なくする目的で, リニアック X 線との混合照射を, 照射野が原発巣のみ のときには，速中性子線単独を原則とした。 Staging Operationを実施した場合 $\mathrm{pN}_{0}$ および $\mathrm{pN}_{1}$ までを放 射線療法の適応として, 最初の 3 例は小骨盤及び原発 巣, 次の 4 例は原発巣のみの照射とした。放射線医学 総合研究所のサイクロトロンが稼動していない期間 に, 放射線療法を開始した例に対し、リニアック X 線 単独照射をした。照射方法は, 速中性子線は前後 2 門, リニアック X 線単独は対向 4 門で行った。線量は, 中 性子線と X 線との算術加算では, 線量を十分に表現で きないため, time dose and fractionation (TDF) と した ${ }^{6)} . \mathrm{TDF} 115$ は, リニアック X 線, $200 \mathrm{rad} \times 35$ 回, 7 週間の線量に相当する. 生存率, 非再発率の算定は, Kaplan-Meier 法により, 有意差の検定は, generalized Wilcoxon testによった。

\section{結果}

A）治療成績：対象症例28例の経過を表 1 亿示し た。観察期間は最短 8 力月, 最長 114 力月, 平均 48 力月 である. 16 (速中性子線21中 11, リンック X 線 7 中 5 ）は，放射線治療のみで制癌されて招り，12（速中

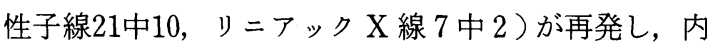
分泌療法（去勢, 直後よりジェチルスチルベステロー ル 2 燐酸 $250 \sim 500 \mathrm{mg} /$ 日約 1 力月投与後，一キセステ ロール30mg/日又はェチニールェステラジオール 1.5 $\mathrm{mg} /$ 日内服したもの 10 , 去勢後酢酸クロルマジノン 100 $\mathrm{mg} /$ 日内服したもの 1 , 転医により去勢十薬剤不明の もの 1) を施行した.

再発様式は, 局所の制御不充分 3 , 遠隔転移十局所 の制御不充分 1 , 遠隔転移のみ 7 , 転医により不明 1 である. 局所の制御不充分例は, いずれも Stage Cで, 1 例を除き前立腺の大半を占める大きな腫瘍であっ た. そのうち 2 例は速中子線照射例であるが, TDF 100，101と低線量であった。遠隔転移例は，骨シンチ にて骨転移が認められたもの 4 , 顉部リンパ節転移 1 , 酸性ホスファターゼ高値であるが，骨シンチにて骨集 積像の認められないもの 3 であった。遠隔転移例の Stage 分布は $\mathrm{B}_{1} 2$ 例, C 6 例であり, 初期の Staging Operation 未施行にも拘らず照射野が前立腺部のみの ものが 3 例あり，他の 5 例中 3 例は TDF 100, 100, 101 と低線量であった。したがって制癌出来なかった原 因として, 大きな原発栄, 照射野設定不良, または低 線量に帰せられた。

内分泌療法追加12例で, 追加直後の 1 例を除いた 11 例中, 同療法で 2 年以上制癌されたものは 7 (64\%) であった．他の 4 例は内分泌療法が無効であったが， いずれも Stage Cであり, 病理組織分化度にて Gleason score 8 が 3 , Gleason score 3 が 1 であっ た。この内分泌療法の反応性の悪かったものは内分泌 療法に损いて，高危険群と考えられるものであった ${ }^{77}$.

表 2 は, Gleason score の Stage 別分布および前立 腺癌取扱い規約の組織学的分類に打ける分化度の Stage 別分布であるが, Stage が進むにつれ, 前者の増 点と後者の低分化傾向が認められた。 これも，一般に 認められていることである8). 表 3 は, Gleason score と追加療法の有無との関係であるが, 内分泌療法追加 のものは, Gleason score 2 4 4 では, 33\%, 5〜 7 で は43\%，8～10では $46 \%$ と Gleason score の増点にと もない内分泌療法追加の比率が増加した. 前立腺癌取 扱い規約の組織学的分類における分化度との場合も, 
表 1

放射線照射後再発をみない例

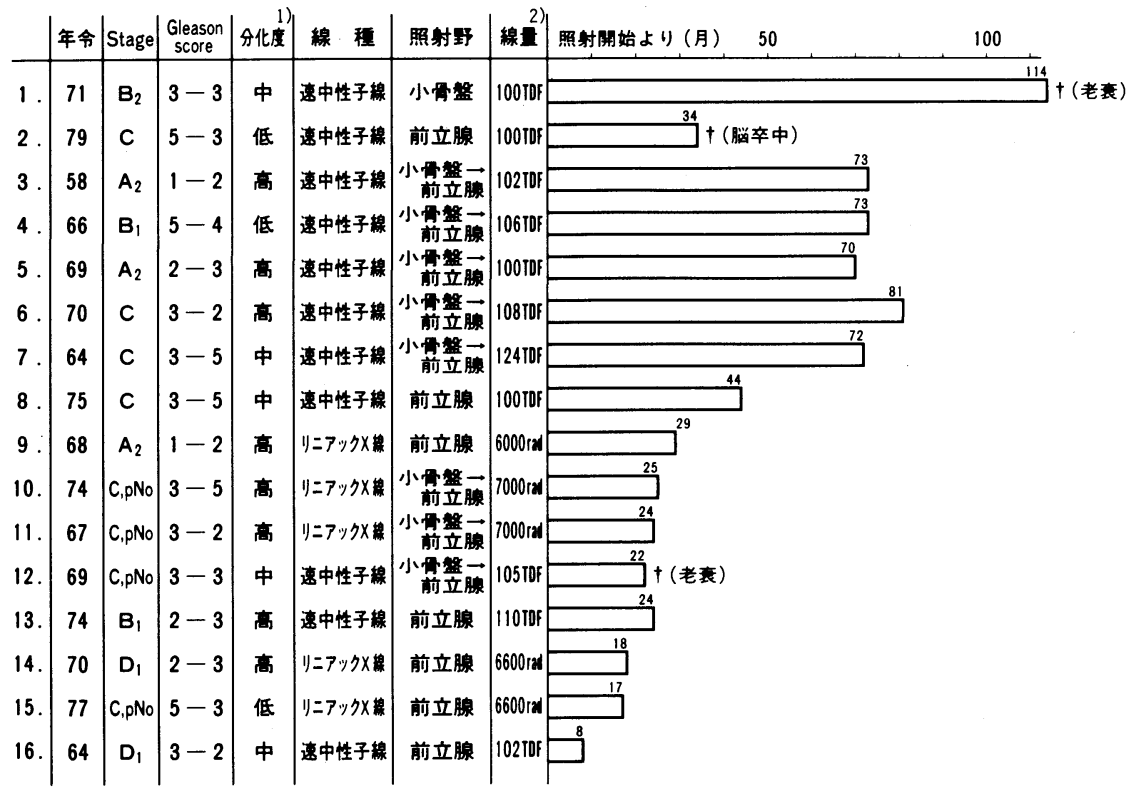

放射線照射後内分泌療法追加例 W内分泌虚法追加開始からの期間

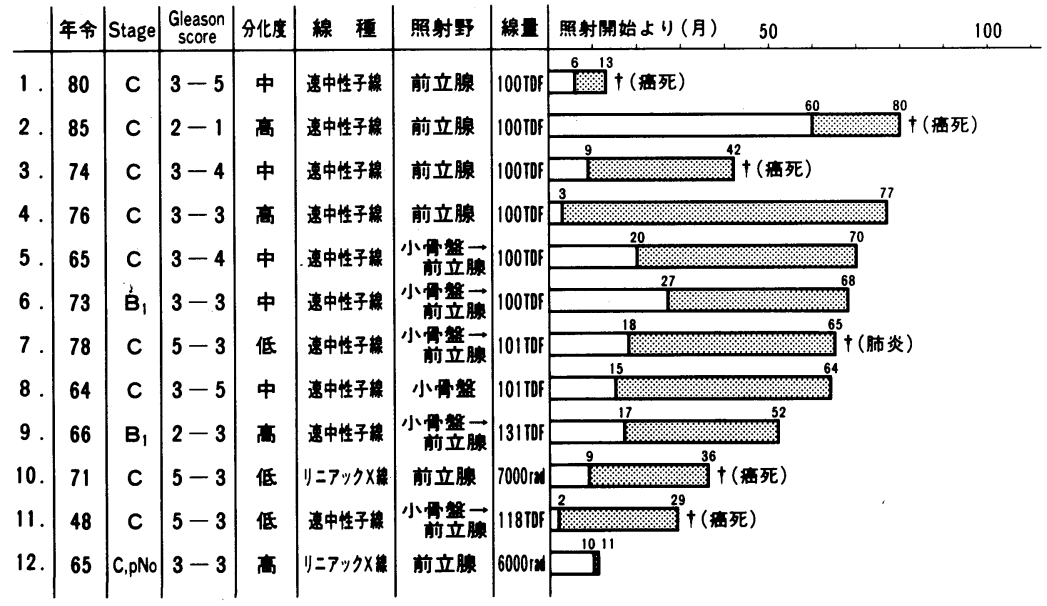

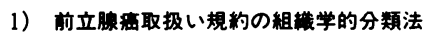

2) TDF : time dose and fractionation
ほぼ同様の傾向をみた。

Stage Cに拈いて, 高分化型は低分化型よりも有意 に良い治療成績を示した(図 1)，放射線治療開始から 再発までの期間を求め, 非再発期間を算定した(図 2 ). Stage $\mathrm{A}_{2} \mathrm{~B} ， \mathrm{C}$ で再発したものは，おのおの $0 ， 2$ ， 10 であり, 3 年非再発率は, Stage $A_{2} 100 \%$, Stage B 53\%, Stage C 52\%であった. Stage Cに执いては
Gleason score の増点と前立腺癌取扱い規約の組織学 的分類に打ける分化度の低分化傾向にともない， 3 年 非再発率は低下した。すなわち, Gleason score 2４ が 1 例のみのため, Gleason score $2 \sim 7$ と Gleason score 8 １0に分けると，それぞれ $54 \% ， 48 \%$ ぞり， 又, 高分化型 $71 \%$, 中分化型 $44 \%$, 低分化型 $30 \%$ であっ た。 
表 2

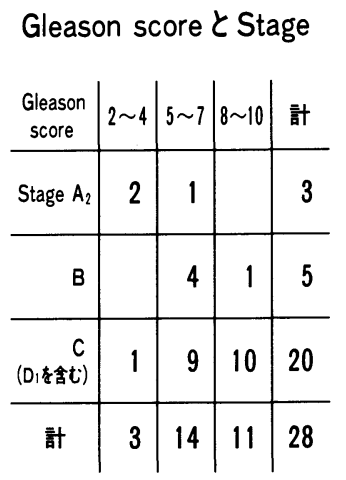

前立腺癌取扱い規約組織学 的分類と Stage

\begin{tabular}{|c|c|c|c|c|}
\hline Stage $\mathrm{A}_{2}$ & 3 & & & 3 \\
\hline B & 2 & 2 & 1 & 5 \\
\hline 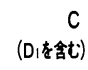 & 7 & 8 & 5 & 20 \\
\hline 計 & 12 & 10 & 6 & 28 \\
\hline
\end{tabular}

表 3 Gleason score と追加療法の有無

\begin{tabular}{|c|c|c|c|c|}
\hline $\begin{array}{l}\text { Gleason } \\
\text { score }\end{array}$ & $2 \sim 4$ & $5 \sim 7$ & $8 \sim 10$ & at \\
\hline 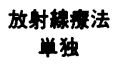 & 2 & $8(2)$ & $6(1)$ & $16(3)$ \\
\hline 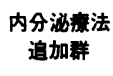 & $1(1)$ & $6(1)$ & $5(4)$ & $12(6)$ \\
\hline It & $3(1)$ & $14(3)$ & $11(5)$ & $28(9)$ \\
\hline
\end{tabular}

（）死亡例

Stage $\mathrm{A}_{2}, \mathrm{~B}, \mathrm{C}$ の実測 5 年生存率はそれぞれ $100 \%$, 100\%，59\%であった（図は示さず）. Stage C を放射 線照射単独例 ( $\mathrm{A}$ 群), 内分泌療法追加例 (B 群) に分 け，1961年から1985年をでの期間に初回治療として去 勢およびジェチルスチルベステロール2燐酸250～500 $\mathrm{mg} /$ 日以降へキセストロール $30 \mathrm{mg} /$ 日あるいはェチ ニールェストラジオール $1.5 \mathrm{mg} /$ 日又は酢酸クロルマ ジノン $100 \mathrm{mg}$ /日を内服した 46 例 (C 群)と比較すると, 生存曲線が $\mathrm{A}$ 群は B, C 群と比し良い傾向をみたが, 統計的な有意差はなかった（図 3 ）.

B）死因：全28例のうち, 死亡は 9 例である.このう ち癌死は 5 例 $\left(56 \%\right.$ ) で, Stage $A_{2}, B$ では癌死はな く, 全て Stage Cであった。他病死は，老衰 2 例，肺 炎 1 例, 脳卒中 1 例であった。

C) 放射線障害: 膀胼刺激症状, 皮膚糜燗などの早 期放射線障害は，治療の継続を妨げるものはなく，晚 期放射線障害は, 尿失禁 3 ( 2 は TUR 後の障害, 1 は 原因不明), 仙骨部裖瘡 2 , 陰茎屈曲 2 , 血便 2 , 尿道 狭窄 1 , 持続する下琍 1 , 計11例に認められたが，外 科的処置が必要であったものは，仙骨部褯瘡の 1 例の みであった。

図 1 放射線療法 Stage $C$ 組織分化度別予後
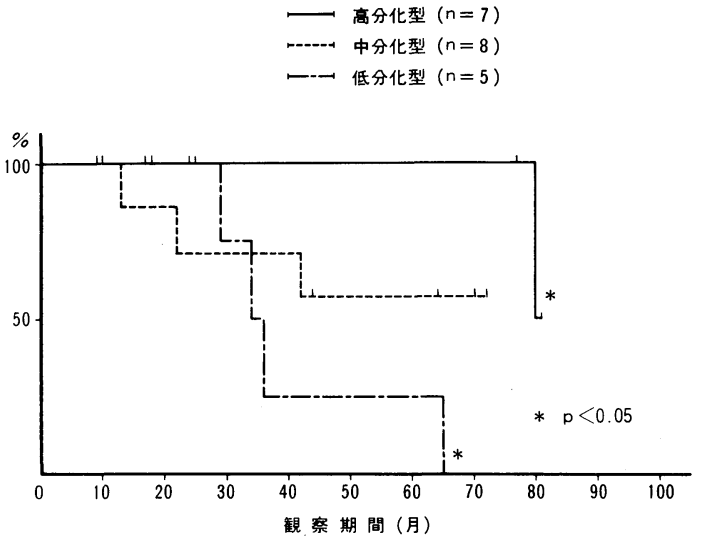

図 2 非再発期間

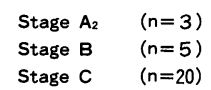

Stage A2, Stage B, Stage Cの間に有意座なし

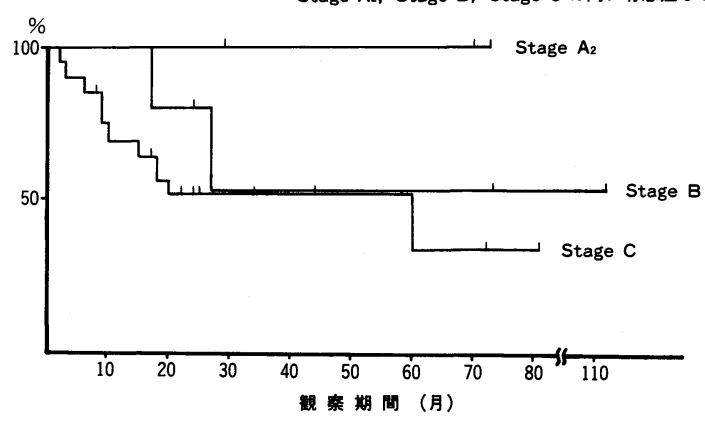

図 3 Stage $\mathrm{C}$ の生存曲線

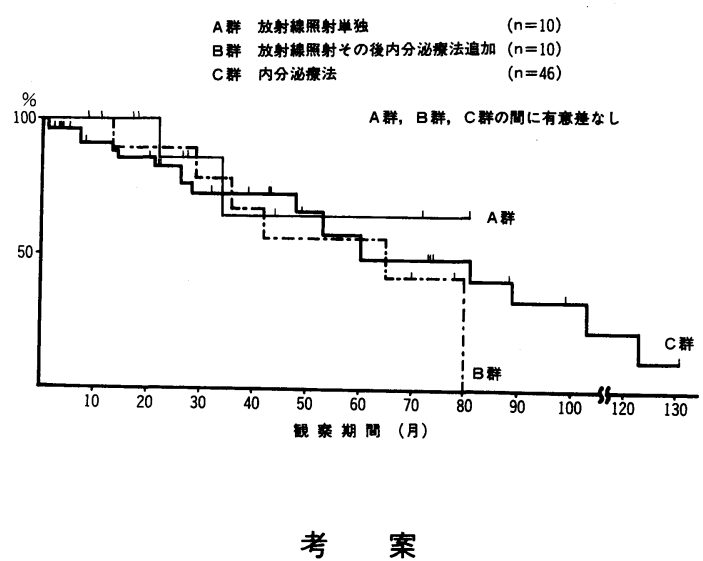

骨盤内限局前立腺癌の治療法として, 根治的前立腺 全摘除術が行なわれているが，同施行例においては 0 ～5\%の術後死亡と $10 \sim 60 \%$ の尿失禁の合併症の危険 


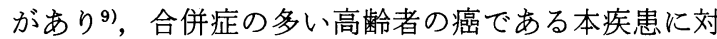
する実施は，未だ問題が多く，本邦においては一般的 な治療法に至っていない，一方，放射線療法は，手術 療法にみる合併症がないら光に, 制癌効果が強く，ほ ぼ手術療法と同じ生存率のため欧米では広く普及して きた ${ }^{10)}$.

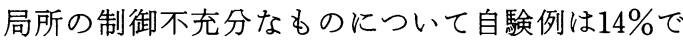
あったが，これはCupps らの報告 ${ }^{11} 14 \%$ と同じであ る. Aristizabal ら ${ }^{12)}$ は Stage C の局所の再発率を 3 施 設で比較しており，Stage Cでは，局所の再発はそれ ぞれ $25 \% ， 13 \% ， 12 \%$ であったという．自験例の局所 制御不充分例は, いずれも Stage Cであり, 同 Stage の $20 \%$ であった．照射方法の改善が必要なことであろ う.高橋ら ${ }^{13)}$ は, あらかじめエストロゲンなどにより原 発巣を縮小してのち照射することを主張して括り，こ れも一つの方法と考学られる。

非再発期間は，前立腺癌の制御についての放射線療 法の有効性をそのまま反映するために重要である。

Stage，Grade と放射線療法後再発するまでの期間は 良く相関するといら報告もあるが，自験例でも同様の 傾向をみた。

骨盤リンパ節転移は，Stage $\mathrm{A}_{2}$ の $23 \%$ ， Stage $\mathrm{B}_{1}$ の 15 20\%, Stage $\mathrm{B}_{2}$ の $35 \%$, Stage $\mathrm{C}$ の $50 \%$ によれ るとされ ${ }^{14)}$ ，当教室では Stage C で71\%の陽性率をみ た ${ }^{15)}$. Stage Cに扔いて，前立腺部のみの照射と全骨 盤十前立腺照射を比較した場合， 5 年生存率， 3 年非 再発率とも後者の成績がよかったという ${ }^{16)}$. 自験例に おいても, Staging Operation 未施行の Stage Cで, 照射野が前立腺部のみである初期例 7 例 5 例が再発し て扣り, Staging Operation未施行にてリンパ節転移 の有無が不明な場合には，骨盤部に照射野を広げる必 要性は当然であろう。しかし，Smith ら ${ }^{17)}$ は， $\mathrm{N}(+)$ の骨盤内照射をした $72 \%$ は 5 年以内に再発（局所，全

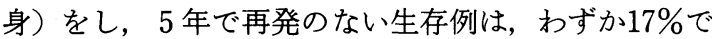
あったとしており， $\mathrm{N}(+)$ の予後は不良である. $\mathrm{N}(+)$ に対して，照射野を傍大動脈リンパ節を含む領域をで 抎大しても，生存にはほとんど影響をおよぼさないと い5 ${ }^{18)}$. 以上のことから， $\mathrm{N}(+)$ 例には，放射線療法 のみでは，根治できないといえる。しかし，本報告の 2 例はいずれも $\mathrm{pN}_{1}$ であり，観察期間は 8 カ月，18力 月と短いが，再発をみていない。

放射線療法にて再発しても，その $64 \%$ が内分泌療法 にて 2 年以上制癌し得たので，一般に約 $80 \%$ の前立腺 癌が内分泌療法に反応するとされている7)ことを考兄
ると，放射線療法を先行させ，無効例に対しての内分 泌療法の治療効果は期待出来るといえる。

放射線療法による 5 年生存率を Stage Cのそれで 比較すると, Harisiadis ら ${ }^{19} 58 \%$, 高橋ら ${ }^{13)} ， 59 \%$, Aristizabal $5^{12} 60 \%$, Bagshaw ${ }^{101} 60 \%$, Rosen $5^{201}$ $61 \%$ と約 $60 \%$ が多く，自験例でも59\%であった。しか し Kurup ら ${ }^{21)} 74 \%$, Ploysongsang ら ${ }^{16)} 81 \%$ と更に良 好な成績も近年みられているので，照射方法の改善が 必要なことである。多くの報告は, Staging Operation 未施行例であり，約半数の $\mathrm{N}(+)$ が含まれているの で, C, $\mathrm{pN}_{0}$ の放射線療法の治療成績は，更に向上する と考えられ，適応の選択が必要であろう。

放射線療法の治療成績は，内分泌療法の本邦報告例 に扮ける 5 年生存率である高安 ${ }^{22} 51 \%$, 竹内ら ${ }^{231}$ $45 \%$, 丸岡ら ${ }^{24} 50 \%$ と比較すると, 幾分良好であり, こ れは照射による局所の制癌効果が，内分泌療法とくら べ，同程度以上に強力であることを示している，アメ リカでは，ここ10年間で Stage C に打ける放射線療法 の割合が著増しており, 根治的前立腺摘出術は減少し ている ${ }^{25)}$. 後者の良好な治療成績の報告 ${ }^{26) 27)}$ もあが, 本邦に扮いても, Stage C 以下の前立腺癌に拈ける放 射線療法は，今後一層一般的なものになるであろう。

速中性子線は, 低酸素細胞に与える効果が強く, 腫 瘍細胞の致死障害からの回復を遅らせることが特徵で ある. Laramore ら ${ }^{28}$ によれば, 局所の制御や生存率に ついて, 速中性子線とリニアック X 線との混合照射術 は，リニアック X 線単独照射例よりも良好な成績で あったという.今回の報告ではリニアック X 線のみの 施行例は, 観察期間が短かく, 症例数も少ないため速 中性子線施行例との治療成績の比較検討が出来なかっ た。しかし，両方法とも現時点では同様の制癌効果を みた。

速中性子線は，脂肪組織に， X 線よりも14\%多く吸 収されるとされ，皮膚及び皮下組織の放射線損傷が懸 念されたが，外科的処置を必要としたものは 1 例のみ であった。

\section{結 語}

1976年から1985年までに，千葉大学医学部泌尿器科 を受診した骨盤内限局の未治療前立腺癌28例に対し て, 速中性子線又はリニアック X 線による放射線療法 を施行し，以下の結論を得た。

1. 放射線療法で制癌中 16 例, 再発し内分泌療法を追 加したもの12例であり，制癌し得なかった原因は，大 きな原発巣，照射野設定不良，低線量に帰せられた。 
2. Stage $\mathrm{A}_{2}, \mathrm{~B}_{1}, \mathrm{C}$ の 3 年非再発率はそれぞれ $100 \%, 53 \%, 52 \%, 5$ 年生存率は $100 \%, 100 \%, 59 \%$ であった。

3. 内分泌療法を追加したものの $64 \%$ 方有効である ことょり，放射線療法後に再発した場合でも内分泌療 法は有効なことが示唆された。

4. 放射線障害で, 外科的処置が必要であったのは仙 骨部裷瘡の 1 例のみであった。

本研究の一部は厚生省がん研究助成金によった。

\section{文 献}

1) Bagshaw, M.A., Kaplan, H.S. and Sagerman, R. H. : Linear accelerator supervoltage radiotherapy. VII. Carcinoma of the prostate. Radiotherapy, 85, 121-129, 1965.

2) Tsuya, A., Kawai, T., Fukushima, S., Shida, K., Shimazaki, J., Matsumoto, K. and Seto, T.: Radiotherapy combined with hormone therapy for prostate cancer. Strahlentherapie, 148, $24-34,1974$.

3）丸岡正幸, 安藤 研, 野積邦義, 伊藤晴夫, 島崎 淳, 松㟢 理, 森田新六, 恒元 博：前立腺癌の速 中性子線療法。日泌尿会誌, 74, 409-417, 1983.

4) Gleason, D.F. and The Veterans Administration Cooperative Urological Research Group : Histologic grading and clinical staging of prostatic carcinoma. in Urological Pathology : The Prostate, p. 171-197, Lea \& Febiger, Philadelphia, 1977.

5) 日本泌尿器科学会, 日本病理学会編：前立腺癌取 扱い規約，第 1 版，66-79, 1985.

6) Orton, C.G. and Ellis, F.: A simplification in the use of the NSD concept in practical radiotherapy. Brit. J. Radiol., 46, 529-537, 1973.

7）島崎 淳, 伊藤晴夫, 宮内大成, 布施秀樹, 井坂茂 夫：前立腺癌の内分泌療法. Oncologia, 10, 82-98, 1984.

8）島崎 淳, 布施秀樹, 座間秀一：前立腺癌. 癌の臨 床, 31，1195-1201， 1985.

9) Nichols, R.T., Barry, J.M. and Hodges, C.V.: The morbidity of radical prostatectomy for multifocal stage I prostatic adenocarcinoma. J. Urol., 117, 83-84, 1977.

10) Bagshaw, M.A.: Potential for radiotherapy alone in prostatic cancer. Cancer, 55, 2079 $-2085,1985$.

11) Cupps, R.E., Utz, D.C., Fleming, T.R., Carson, C. C., Zincke, H. and Myers, R.P.: Definitive radiation theapy for prostatic carcinoma: Mayo Clinic Experience. J. Urol., 124, 855-859, 1980.
12) Aristizabal, S.A., Steinbronn, D. and Heusinkveid, R.S.: External beam radiotherapy in cancer of the prostate. Radiother. Oncol., 1, 309-315, 1984.

13）高橋 卓, 河合恒雄, 䉆塚 誠, 楠山弘之：前立腺 癌 Stage C に拈けるェストロジェン先行・放射線 治療の試み。臨泌，40，225-229，1986.

14) Donohue, R.E., Fauver, H.E., Whitesel, J.A., Augspurger, R.R. and Pfister, R.R.: Prostatic carcinoma. Influence of tumor grade on results of pelvic lymphadenectomy. Urology, 17, 435-440, 1981.

15）布施秀樹, 座間秀一, 秋元 晋, 島崎 淳, 松㟷 理, 村上信乃, 五十嵐辰男：前立腺癌の staging pelvic lymphadenectomy. 泌尿紀要, 32, 1465 $-1470,1986$.

16) Ploysongsang, S., Scott, R.M., Aron, B.S., Ho, P.Y., Shehata, W.M., Morand, T.M. and Jazy, F.K.: Comparison of whole pelvis versus small-field radiation therapy for carcinoma of prostate. Urology, 27, 10-16, 1986.

17) Smith, J.A., Haynes, T.H. and Middleton, R.G. : Impact of external irradiation on local symptoms and survival free of disease in patients with pelvic lymph node metastasis from adenocarcinoma of the prostate. J. Urol., 131, 705-707, 1984.

18) Sause, W.T., Richards, R.S. and Plenk, H.P. : Prostatic carcinoma: 5-year follow up of patients with surgically staged disease undergoing extended field radiation. J. Urol., 135, 517-519, 1986.

19) Harisiadis, L., Veenema, R.J., Senyszyn, J.J., Puchner, P.J., Tretter, P., Romas, N.A., Chang, C.H., Lattimer, J.K. and Tannenbaum, M.: Carcinoma of the prostate: Treatment with external radiotherapy. Cancer, 41, 2131-2142, 1978.

20) Rosen, E.M., Cassady, J.R., Connolly, J. and Chaffey, J.T.: Radiotherapy for localized prostatic carcinoma. Int. J. Radiat. Oncol. Biol. Phys., 10, 2201-2210, 1984.

21) Kurup, P., Kramer, T.S., Lee, M.S. and Phillips, R.: External beam irradiation of prostate cancer. Cancer, 53, 37-43, 1984.

22）高安久雄, 小川秋実, 小磯謙吉, 小峰志訓, 石井泰 憲：前立腺癌の治療成績。日泌尿会誌, 69, 426-435, 1978.

23）竹内弘幸, 山内昭正：前立腺癌の hormone 療法に おける継続的 estrogen 投与の意義に関する臨床 的研究. 日泌尿会誌, 69, 1552-1561，1978.

24）丸岡正幸, 安藤 研, 野積邦義, 安田耕作, 伊藤晴 
夫, 島崎 淳, 松㟢 理, 村上信乃：前立腺癌の内 分泌療法。日泌尿会誌，73，432-437, 1982.

25) Schmidt, J.D., Mettlin, C.J., Natarajan, N., Peace, B.B., Beart, R.W. Jr., Winchester, D.P. and Murphy, G.P.: Trends in patterns of care for prostatic cancer, 1974-1983: Results of surveys by the American College of Surgeons. J. Urol., 136, 416-421, 1986.

26) 千葉隆一, 石井延久, 常盤峪士, 目時利林也: 前立 腺癌に対する経恥骨式前立腺全摘出術症例の術後 成績とその予後. 日泌尿会誌, 72, 407-415, 1981.
27) Schroeder, F.H. and Belt, E.: Carcinoma of the prostate: A study of 213 patients with stage C tumors treated by total perineal prostatectomy. J. Urol., 114, 257-260, 1975.

28) Laramore, G.E., Krall, J.M., Thomas, F.J., Griffin, T.W., Maor, M.H. and Hendrickson, F. R. : Fast neutron radiotherapy for locally advanced prostate cancer : Results of an RTOG randomized study. Int. J. Radiat. Oncol. Biol. Phys., 11, 1621-1627, 1985.

(1987年 2 月 16 日受理) 